\title{
Implementation of Mobile Payment in Indonesia
}

\author{
Retno Fuji Oktaviani, Dewi PuspaningtyasFaeni, Ratih PuspitaningtyasFaeni, Rinny \\ Meidiyustiani
}

\begin{abstract}
Indonesia is one country that has implemented several electronic payment, including storing and using electronic money. In Indonesia many products that dikelurkan electronic money banks and private parties. Examples of some mobile payment products in Indonesia is Ovo, Doku, Gopay and more as products are developed from large companies in Indonesia. This study was to determine the factors that affect the adoption of the use of electronic money in Indonesia as an alternative means of payment. Respondents Data obtained from filling the form online at Google form, which links its spread through social media such as Facebook, Twitter, and online forums. The target respondents are people who never used a mobile payment. Data were analyzed using multivariate technique structural equation modeling (SEM) using software LISREL 8. Results of data processing shows that the factors that affect the acceptance of mobile payment is electronic wordof-mouth (e-WOM), trust, perceived risk and perceived ease of use.
\end{abstract}

\section{Introduction}

The development of non-cash transactions have a significant increase worldwide. The development of noncash payments globally from 2007 to 2011 (Capgemini, 2013) [1]. In 2010 to 2011 has increased by around $8.8 \%$ and reached 307 trillion in transactions. Growth was led by the region of Central Europe, Middle East, Africa (CEMEA), and developing Asian countries (Emerging Asia). The region has a total non-cash transactions globally are small, but the amount of investment in this sector helped the region has a significant development. The countries in the region had a market share the most, namely by $6.5 \%$ globally and increased $21.9 \%$ in 2011 [2-3]. Ernst and Young (2011) stated that mobile payment services in 2014 had a value of transactions reached $\$ 245$ billion and has 340 million users worldwide, which equals the total to $5 \%$ of all mobile users around the world. Figure 1.2 explains that the Asia-Pacific region is the region that has the largest percentage of the world's mobile payment compared to other regions [4-5].

According to analysis by Ernst and Young (2011), a type of non-cash payments which have significantly improved is through the medium of mobile. Penetration of mobile payments have the percentage reached $83 \%$, exceeding the payment transactions via the Internet, POS, and others [6-9]. Revised Manuscript Received on July 05, 2019.

Retno Fuji Oktaviani,

Faculty of Economics and Business Universitas Budi Luhur, Jakarta, Indonesia, retno.fujioktaviani@budiluhur.ac.id
This is due to the use of mobile payment is considered to have speed in the transaction. Based on data from the Association of Indonesian Internet Service Provider (APJJI), smartphone penetration is expected to reach $80 \%$ in 2011 and could continue to rise [10-12].

One type of mobile payment is an e-wallet. According replied (2008), e-wallet can replace the use of cash, with the proviso that, the e-wallet should facilitate transactions without carrying cash is thick and heavy and e-wallet should reduce the user performs the calculation of transactions in order to speed up payments and e-wallet must improve security and reduce the risk of loss from theft and ensure the anonymity of the payment [13-15].

Based on a survey conducted in Lu et al. (2011), consumers who do not have the trust of the mobile payment can be inhibiting the development of mobile payment industry for $73.5 \%$ of consumers worry about security and transaction risk when using mobile payment services. Therefore, building consumer confidence is very important to help the adoption of mobile payment and it is the key to success in business in this industry [16-19].

\section{Literature Review \\ 2.1. Mobile Payment}

E \& Y (2011) grouping of mobile payment based technologies and scenarios. Based on the technology, mobile payment is divided into three sections: Short Messaging Service (SMS), Near Field Communication (NFC) and Mobile Internet [20-22]. For the division based on the scenario, mobile payment is divided into six parts, namely the payment type, use case, characteristics, examples, payment providers and enablers, and mobile operator participation [23-25].

\subsection{Electronic Wallet}

Mobile payment is included in the category of electronic wallet, which included non-cash transactions, not using media such as cards, and conduct transactions via electronic channels (Amoroso, 2011)[26]. In contrast to the debit card or credit card, using the e-wallet transactions indirectly through a third party or intermediary (Amoroso, 2011) [2728].

E-wallet is growing not because of the mobile wallet is used to facilitate e-wallet, but for their mobile devices

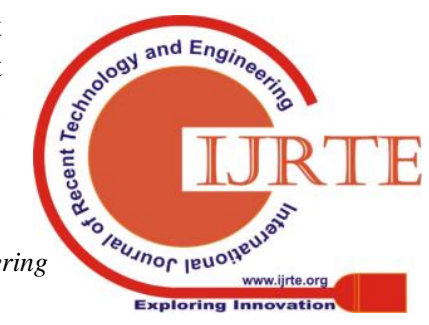


owned by virtually everyone and this triggers the use of mobile devices as an intermediary for the e-wallet (Olsen, 2011). Mobile payment is present not as a substitute for cash transactions, but as a complement to cash (Olsen, 2011). The success of Paypal as a means of transactions on e-commerce world shows that there is a need in the world of e-commerce to an alternative transaction tool. Environment for e-wallet is still immature and open wide the opportunity to plunge into the world of e-wallet pose competition for the business. Institutions to non-bank banks flocked e-wallet to make products for sale kepasaran. E-wallet environment finally gets crowded and the increasing number of competitors makes the competition in the world of e-wallet is getting fierce [29-30].

\subsection{Technology Accetpance Model}

One of the studies most to the adoption of technologies for the individual is the Technology Acceptance Model
(TAM). Davis (1989) introduces TAM to explain about the habits of users to use the computer. The study explains that TAM is suitable for user acceptance of the computer. In addition to TAM actually there are many other methods on user adoption. such uses and gratification or diffusion of innovation, but for mobile payment research, TAM is more suitable because it can be modified as necessary factors in the adoption of user acceptance (Shin, 2009) [31].

TAM is derived from the theory of reasoned action which explains that the attitude toward using and subjective norm has an influence on behavioral intention to use, which in turn affect the actual usage is illustrated in Figure 1. The TAM is the first method that can apply psychological factors on information systems and adoption computer. The main variables in TAM that most affect the user to use a technology is perceived usefulness and perceived easy of use (Davis, 1989) [32]. Research now many developing TAM by adding factors that according to the research conducted

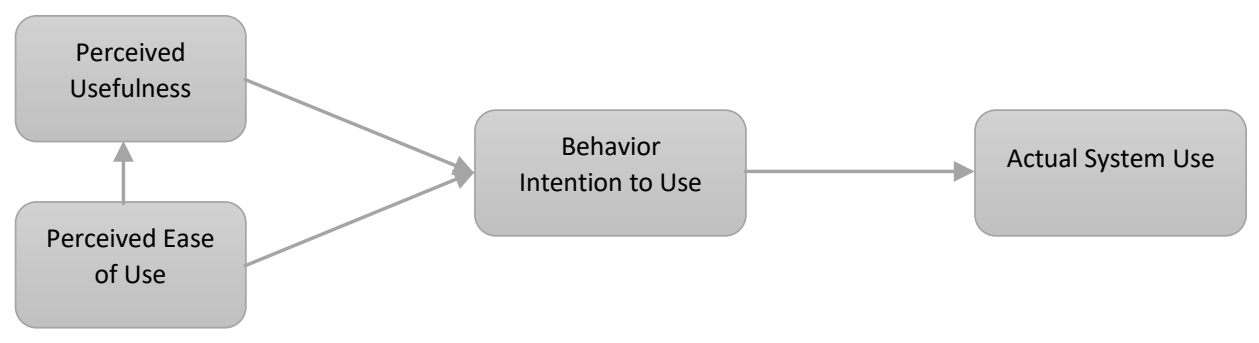

Figure 1. TAM By Davies et. al.

\section{Research Methodology}

The approach used in this study is quantitative. This method is called quantitative because the research data in the form of figures and statistical analysis used (Sugiyono, 2013). A quantitative approach is the approach taken by the measurement of the variables of a subject. A quantitative approach is used to determine the sample persespsi study of model studies that have been made.

The research model using Structural Equation Modeling (SEM) is a technique that uses applied multivariate statistical analysis methods used by various groups (Pugesek \& Tomer, 2003). Although there are various techniques that show up early, SEM more attractive than other techniques. This is because there is a lot of special applications for SEM such as AMOS, EQS, LISREL, Mplus, Mx, RAMONA, SEPATH. Another thing that makes SEM increasingly used is the number of publications using SEM techniques. It facilitates access to information on SEM easier.

Shipley (2000) in Pugesek \& Tomer (2003) states SEM in a broad sense as a set of hypothetical causal relations between the variables with the hypothesis composites based on patterns that are dependent statistical dependencies. This relationship is described by the parameter that indicates the magnitude of the effect (directly or indirectly) the independent variable (either observed or latent) on the dependent variable (either observed or latent) (Pugesek \& Tomer, 2003).

\section{Research Result}

SEM test the feasibility of the model with 2 stages commonly called two steps SEM process. The first stage is to test the measurement model, and the second stage is to test the structural model. Test models of measurement used to determine how precisely the manifest variables explain existing latent variables. Structural model test is used to determine whether there is a relationship between the latent variables that exist in the proposed model.

The author uses the standard for the standardized loading factors $>0.5$. because the data used did not support the standardized loading factors $>0.7$ Table 1 . can be seen the value of the model test measurements carried out in this study.

Table 1. Test Validity and Reliability Model

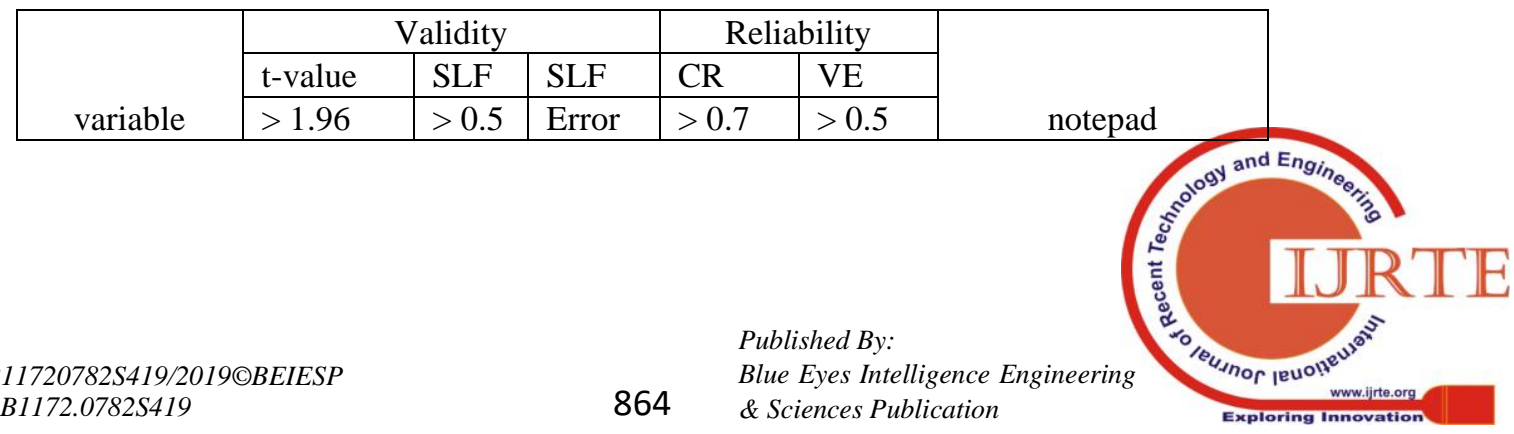




\begin{tabular}{|l|l|l|l|r|r|l|}
\hline \multicolumn{2}{|l|}{ perceived Risk } & $\boldsymbol{0 . 8 9}$ & $\mathbf{0 . 7 6}$ & Good Reliability \\
\hline RSK1 & 9.85 & 0.92 & 0.12 & & & Good Validity \\
\hline RSK2 & 9.76 & 0.54 & 0.45 & & & Good Validity \\
\hline RSK3 & 9.67 & 0.87 & 0.19 & & & Good Validity \\
\hline \multicolumn{7}{|l|}{ Perceived Ease of Use } \\
\hline EOI1 & 5.23 & 0.68 & 0.52 & & & Good Validity \\
\hline EOI2 & 7.8 & 0.61 & 0.32 & & & Good Validity \\
\hline EOI3 & 3.56 & 0.52 & 0.59 & & & Good Validity \\
\hline perceived Value & 0.88 & 0.94 & 0.25 & & & Good Validity \\
\hline val1 & 0.76 & 0.81 & 0.32 & & & Good Validity \\
\hline val2 & 6.13 & 0.38 & 0.68 & & & Good Validity \\
\hline $\boldsymbol{e}$-Wom & 5.87 & 0.65 & 0.42 & & & Good Validity \\
\hline EWM1 & 5.58 & 0.42 & 0.57 & & & Good Validity \\
\hline EWM2 & 7.98 & 0.79 & 0.22 & & & Good Validity \\
\hline EWM3 & 8.69 & 0.98 & 0.11 & & & Good Validity \\
\hline Trust & 8.76 & 0.92 & 0.08 & & & Good Validity \\
\hline TRS1 &
\end{tabular}

Table 2. Goodness of Fit Test

\begin{tabular}{|l|l|r|l|}
\hline criteria & standart & Estimate Result & Match Level \\
\hline Normed Chi-Square (X2 / df) & $<2$ & 1.58 & Good Fit \\
\hline RMSEA & $<0: 08$ & 0.03 & Good Fit \\
\hline NFI & $>0.9$ & 0.98 & Good Fit \\
\hline NNFI & $>0.9$ & 1.00 & Good Fit \\
\hline CFI & $>0.9$ & 1.00 & Good Fit \\
\hline GFI & $>0.9$ & 0.91 & Good Fit \\
\hline standarized RMR & $<0: 05$ & .058 & marginal Fit \\
\hline
\end{tabular}

The results of goodness of fit test on measurement models show that the normed chi-square value, RMSEA, NFI, NNFI,
GFI and CFI meet the criteria of the standard. So the research model fit for use.

Table 3. Test of Hypothesis

\begin{tabular}{|c|c|c|c|}
\hline hypothesis & estimates & Value-t & Result \\
\hline PR-> TR & 0.78 & 3.15 & significant \\
\hline PV-> TR & 0.56 & 2.8 & significant \\
\hline Ewom-> TR & 0.89 & 4.52 & significant \\
\hline TR-> PEU & 0.65 & 3.39 & significant \\
\hline
\end{tabular}

From the test results, there are four structural models that have an influence sgnifikan relationship that PR-> TR, PV-> TR, Ewom-> TR, TR-> PEU. So it can be concluded that all the

factors have a significant influence.

\section{Conclusion}

The results showed the model established by the TAM model is modified by adding factors that are considered the author has an influence on acceptance of mobile payment in Indonesia based on previous research. TAM recognized can model the user acceptance of the system. However, it takes additional variables to help TAM in order to explain the situation more deeply.

The factors used in this study is the perceived ease of use, trust, perceived risk, perceived value, and e-WOM. A sense of confidence in a product having a very influential factor on the use of mobile payment. Proven in this study, trust is more influential than perceived risk belonging to TAM. In this study, a sense of trust was raised by perceived ease of use, e-WOM, and perceived risk. The most influential relationship is the relationship between e-WOM with trust.

Ethical clearance - Not required

Source of funding- Self 


\section{Conflict of Interest - Nil}

\section{References}

[1] Amoroso, DL, \& Magnier-Watanabe, R. (2012). Building a research models for consumer adoption of mobile wallet: the case of mobile Suica in Japan. Journal of theoretical and applied electronic commerce research, 7 (1), 94-110.

[2] Bansal, HS, \& Voyer, PA (2000). Word-of-mouth processes within a services purchase decision context. Journal of service research, 3 (2), 166-177.

[3] Byrne, BM (2001). Structural equation modeling with AMOS, EQS, and LISREL: Comparative approaches to testing for the factorial validity of a measuring instrument. International Journal of Testing, 1 (1), 55-86.

[4] Chau, PY (1996). An empirical assessment of a modified technology acceptance models. Journal of management information systems, 13 (2), 185-204.

[5] Chen, JJ, \& Adams, C. (2005, December). User acceptance of mobile payments: a theoretical models for mobile payments. In the 5th International Conference on Electronic Business, Hong Kong, December (pp. 5-9).

[6] Chen, LD, Gillenson, ML, \& Sherrell, DL (2002). Enticing online consumers: an extended technology acceptance perspective. Information \& Management, 39 (8), 705-719.

[7] Cheong, JH, Park, MC, \& Hwang, JH (2004, September). Mobile payment adoption in Korea: Switching from credit card. In ITS 15th Biennial Conference, Berlin, Germany, September (pp. 4-7).

[8] Cheung, MY, Luo, C., Sia, CL, \& Chen, H. (2009). Credibility of electronic word-of-mouth: Informational and normative determinants of on-line consumer Recommendations. International Journal of Electronic Commerce, 13 (4), 9-38.

[9] Davis, FD (1993). User acceptance of information technology: system characteristics, user perceptions and behavioral impacts. International Journal of man-machine studies, 38 (3), 475-487.

[10] Davis, FD, Bagozzi, RP, \& Warshaw, PR (1989). User acceptance of computer technology: a comparison of two theoretical models. Management science, 35 (8), 982-1003.

[11] Gefen, D., \& Straub, DW (2004). Consumer trust in B2C ecommerce and the importance of social presence: experiments in e-products and e-services. Omega, 32 (6), 407-424.

[12] Grazioli, S., \& Jarvenpaa, SL (2000). Perils of Internet fraud: An empirical investigation of deception and trust with experienced Internet consumers. Systems, Man and Cybernetics Part A: Systems and Humans, IEEE Transactions on, 30 (4), 395-410.

[13] Kim, HW, Chan, HC, \& Gupta, S. (2007). Value-based adoption of mobile internet: an empirical investigation. Decision Support Systems, 43 (1), 111-126.

[14] Kuo, YF, Wu, CM, \& Deng, WJ (2009). The relationships among service quality, perceived value, customer satisfaction, and postpurchase intention in mobile value-added services. Computers in Human Behavior, 25 (4), 887-896.

[15] Lai, YH (2012). The study of technology acceptance for e-wallets application of clinic fees payment. Health (1949-4998), 4 (11).

[16] Lee, T. (2005). The impact of perceptions of interactivity on customer trust and transaction intentions in mobile commerce. Journal of Electronic Commerce Research, 6 (3), 165-180.

[17] Li, R., Kim, J., \& Park, J. (2007). The effects of internet shoppers' trust on their purchasing intention in China.JISTEM-Journal of Information Systems and Technology Management, 4 (3), 269286.

[18] Lu, J., Yao, JE, \& Yu, CS (2005). Personal innovativeness, social influences and adoption of wireless Internet services via mobile technology. The Journal of Strategic Information Systems, 14 (3), 245-268.

[19] Luo, X., Li, H., Zhang, J., \& Shim, JP (2010). Examining the multi-dimensional and multi-faceted trust risk in the initial acceptance of emerging technologies: An empirical study of mobile banking services. Decision support systems, 49 (2), 222234.

[20] Lu, Y., Yang, S., Chau, PY, and Cao, Y. (2011). Dynamics between the trust transfer process and intention to use mobile payment services: A cross-environment perspective. Information \& Management, 48 (8), 393-403.

[21] Okazaki, S., Katsukura, A., \& Nishiyama, M. (2007). How mobile advertising works: The role of trust in improving attitudes and recall. Journal of Advertising Research, 47, 165-178.

[22] Said, JM (2008). The Adoption and Diffusion of Electronic Wallets: The Case of Moneo. Journal of Internet Banking and Commerce, 13 (1).
[23] Santoso, S. (2012). Using SEM analysis of AMOS. Jakarta: Elex Media Komputindo.

[24] Shin, DH (2009). Towards an understanding of the consumer acceptance of

[25] mobile wallet. Computers in Human Behavior, 25 (6), 1343-1354.

[26] Shin, DH, \& Kim, WY (2008). Applying the technology acceptance models and flow theory to Cyworld user behavior: implication of the web2. 0 user acceptance. CyberPsychology \& Behavior, 11 (3), 378-382.

[27] Siau, K., \& Shen, Z. (2003). Building customer trust in mobile commerce. Communications of the ACM, 46 (4), 91-94.

[28] Sirdeshmukh, D., Singh, J., \& Sabol, B. (2002). Consumer trust, value, and loyalty in relational exchanges. Journal of Marketing, 66 (1), 15-37.

[29] Sugiyono, D. (2013). Qualitative and quantitative research methods R \& D. Bandung: Alfabeta.

[30] Westbrook, RA (1987). Product / consumption-based affective responses and Postpurchase processes. Journal of marketing research, 258-270.

[31] Wijanto, SH (2008). Structural Equation Modeling with lisrel 8.8 Concepts and Tutorials, Graha Science.

[32] Xin, H., Techatassanasoontorn, AA, \& Tan, FB (2013). Exploring the influence of trust on the mobile payment adoption. 2013 Pacific Asia Conference on Information Systems. Jeju Island, South Korea. 